\title{
How to pay for national pharmacare
}

\author{
Michael C. Wolfson PhD, Steven G. Morgan PhD
}

Cite as: CMAJ 2018 November 26;190:E1384-8. doi: 10.1503/cmaj.180897

CMAJ Podcasts: author interview at https://soundcloud.com/cmajpodcasts/180897-ana

$\because$ anada has long been the only high-income country with a universal health insurance system that excludes universal coverage of prescription drugs. But the 2018 federal budget established the Advisory Council on the Implementation of National Pharmacare to recommend a remedy for this shortcoming of Canadian medicare. ${ }^{1}$ In addition to sorting out program details, such as which medications will be covered, the advisory committee must propose a mechanism for financing national pharmacare.

Not merely of special interest to economists, financing mechanisms influence key pharmaceutical policy outcomes. Access to medicines is best facilitated when direct charges to patients are limited. ${ }^{2}$ Cost control is best achieved by single-payer systems that reduce administration costs and consolidate purchasing power. ${ }^{3,4}$ Financial equity is best promoted by systems that collect contributions in proportion to ability to pay and are independent of needs. ${ }^{5,6}$

For the reasons above, government committees from the 1964 Royal Commission on Health Services to the 2018 Standing Committee on Health have recommended that national pharmacare be analogous to Canadian "medicare": a universal, public program to cover medications on a national formulary at little or no cost to patients who need them. ${ }^{7-10}$ Yet, even if a medicarelike program is the way forward for Canada, and if it can save billions of dollars in pharmaceutical costs, important choices regarding financing remain. How public funds are raised for a national pharmacare program, and how the private sector savings are distributed, will influence fairness, the economy and whether provinces and territories are willing and able to participate. Addressing how to pay for pharmacare is a matter of some urgency, as the window of opportunity for reform could well be the 2019 federal election campaign. We consider the likely cost of pharmacare to the federal government and analyze ways in which the funds might be generated.

\section{What is the estimated cost of pharmacare?}

The Parliamentary Budget Officer recently studied the potential cost of a universal, comprehensive, public pharmacare program - one that would cover all medications on the most extensive public formulary in Canada (Quebec's formulary) at little or no cost to patients. ${ }^{10,11}$ The Officer estimated that the total cost of

\section{KEY POINTS}

- Based on estimates from the Parliamentary Budget Officer, implementing national pharmacare in 2020 will require $\$ 9.7$ billion in new public funding but will save $\$ 13.9$ billion for the private sector, for a net saving of $\$ 4.2$ billion.

- Federal financing of the incremental public cost of pharmacare would encourage provincial participation, pool financial risks across provinces and support fiscal equalization.

- No single revenue source or mix can finance pharmacare without generating larger gains for some payer groups than for others.

- A judicious blend of personal and corporate income tax increases would be a reasonable means of raising necessary revenues and equitably distributing net savings from the program.

- Sophisticated simulation modelling tools exist that can inform policy choices such as details of tax changes needed to raise the needed revenues.

such a national pharmacare program would be $\$ 23.7$ billion in 2020 - a year by which it would be reasonable to expect the program to begin. ${ }^{12}$ Although there is uncertainty about what such a program will actually cost, these estimates are on par with "worst-case scenarios" in peer-reviewed academic studies. ${ }^{13,14}$ The Officer also makes the reasonable assumption that, at least initially, Canada's system will be more expensive than universal, single-payer pharmacare systems in comparable high-income countries, including Australia, New Zealand, Norway, Sweden and the United Kingdom. ${ }^{3,15}$

As summarized in Table 1, the Parliamentary Budget Officer assumes that all but $\$ 500$ million of the cost of drugs on the national formulary would be publicly financed. Private insurance would continue to exist and would likely cover copayments under the public plan, plus drugs not on the national formulary. If the Parliamentary Budget Officer model of national pharmacare were fully implemented in 2020, this would not require $\$ 23.2$ billion in new taxes. By 2020, Canadians would be paying $\$ 13.5$ billion for prescriptions that would be on the national formulary through existing tax-financed public drug plans if national pharmacare were not implemented. ${ }^{12}$ Pharmacare implementation would therefore require only an additional $\$ 9.7$ (i.e., \$23.2 minus \$13.5) billion of public funding. Further, per 
the Parliamentary Budget Officer estimate, Canadians will realize $\$ 13.9$ billion in private sector savings as a result of projected reductions in the cost of private insurance ( $\$ 10.2$ billion) and reduced out-of-pocket expenses (\$3.6 billion).

\section{How much should the federal government pay?}

Leaving aside questions of which level of government would be responsible for the administration and delivery of national pharmacare - which have been discussed in detail by others ${ }^{16}-$ the first financing question is which level of government should be responsible for raising the revenues required for national pharmacare. Because the provinces would otherwise be spending $\$ 13.5$ billion on the drugs that would be covered under the Parliamentary Budget Officer model of national pharmacare, it is reasonable to assume that this level of provincial funding would continue and be folded into the new program. This would leave $\$ 9.7$ billion of new public funding required in 2020, as per the Officer's cost estimates.

The most important reason that this incremental cost of pharmacare should be funded federally is to facilitate provincial participation. Even though health care is largely a provincial responsibility, having the federal government finance a sizable share of the cost of national pharmacare will help ensure that all provinces are financially willing and able to participate and meet national standards. ${ }^{16}$ This is how Canadian medicare came about, and has been the recommendation of numerous commissions and committees that have seen pharmacare as a necessary extension of the Canadian medicare system. ${ }^{7-10}$

In addition, having a substantial budgetary stake in national pharmacare should enable the federal government to play a more coherent and stronger role with regard to drug costs, not only in nationwide bargaining but also with respect to trade, regulation and intellectual property policies that influence availability and costs of pharmaceuticals. ${ }^{17}$

The question of how to finance national pharmacare therefore comes down to how the federal government might raise the $\$ 9.7$ billion of public funding needed, which in turn will determine who in the private sector will benefit from the $\$ 4.2$ billion in net savings the program will generate.

\section{What would be the net cost to the federal government?}

The Parliamentary Budget Officer and Health Canada have already stated that some of the cost of universal, public pharmacare can be recouped through reduced federal tax subsidies for private expenses that will be decreased under the program. ${ }^{12,18}$ The federal government projects that, in 2019, it will provide $\$ 1.76$ billion in medical tax credits given to individuals who incur substantial medical expenses, and $\$ 2.84$ billion in tax expenditures for employer-provided extended health benefits. ${ }^{19}$ These federal tax subsidies are matched by most provincial governments pursuant to the federal-provincial tax collection agreements to the extent that their own income taxes are based on the federal definition of taxable income, so there will also be income tax revenue windfalls to provinces if national pharmacare is implemented in 2020.

Governments will not be able to recoup all of these tax subsidies because they include subsidies for nonpharmaceutical health expenses. However, as prescription drugs account for $41 \%$ of health care financed through private insurance in Canada, the tax subsidies will likely be reduced by about that proportion. ${ }^{20}$ Taking these federal income tax revenue windfalls into account (but ignoring the provincial windfalls) would leave about $\$ 8$ billion of federal government revenue needed to implement national pharmacare in 2020.

\section{What taxes could raise the new funds?}

The major options for raising the \$8 billion in new tax revenue needed to implement national pharmacare include personal income taxes, corporate income taxes, the Goods and Services Tax (GST) and premiums (Table 2). We review the pros and cons of these options one at a time, along with the scale of revenues

Table 1: Financing of prescription drugs with and without universal pharmacare in 2020 *

\begin{tabular}{|c|c|c|c|}
\hline Total expenditure & $\begin{array}{c}\text { Without } \\
\text { pharmacare, } \\
\text { \$ billions }\end{array}$ & $\begin{array}{c}\text { With pharmacare, } \\
\$ \text { billions }\end{array}$ & Change \\
\hline \multicolumn{4}{|l|}{ Drugs on the national formulary } \\
\hline Paid through taxes & 13.5 & 23.2 & 9.7 \\
\hline Paid directly and through private insurance premiums & 14.3 & 0.5 & -13.9 \\
\hline \multicolumn{4}{|l|}{ Drugs not on the national formulary } \\
\hline Paid through taxes & 1.4 & 1.4 & 0.0 \\
\hline Paid directly and through private insurance premiums & 3.2 & 3.2 & 0.0 \\
\hline Subtotal: drugs not on national formulary & 4.6 & 4.6 & 0.0 \\
\hline
\end{tabular}


Table 2: Major options for generating public funding needed to implement pharmacare in $2020^{\star}$

\begin{tabular}{|c|c|c|c|}
\hline Revenue source & $\begin{array}{c}\text { Total revenues } \\
\text { expected in } 2020 \text {, } \\
\text { without pharmacare, } \\
\text { \$ billions }\end{array}$ & $\begin{array}{l}\text { Estimated amount of } \\
\text { funding raised by a } \\
1 \text { percentage point } \\
\text { increase in tax rate, } \\
\$ \text { billions }\end{array}$ & Pros and cons of tax instrument \\
\hline $\begin{array}{l}\text { Personal income } \\
\text { taxes }\end{array}$ & 175.2 & 7.7 & $\begin{array}{l}\text { Pros: large revenue base; progressive } \\
\text { Cons: collects from households only }\end{array}$ \\
\hline $\begin{array}{l}\text { General and small } \\
\text { business corporate } \\
\text { income taxes }\end{array}$ & 49.4 & 2.5 & $\begin{array}{l}\text { Pros: collects from corporations that will benefit from } \\
\text { pharmacare; likely progressive } \\
\text { Cons: potential issues with tax avoidance; strong business } \\
\text { opposition }\end{array}$ \\
\hline GST & 40.6 & 7.9 & $\begin{array}{l}\text { Pros: simple to administer } \\
\text { Cons: collects from households only; regressive; politically } \\
\text { unpopular }\end{array}$ \\
\hline Premiums & - & - & $\begin{array}{l}\text { Pros: transparent } \\
\text { Cons: collects from households only; regressive }\end{array}$ \\
\hline
\end{tabular}

Note: GST = Goods and Services Tax.

*Authors' calculations based on federal budget estimates and Parliamentary Budget Officer tools, including using the Social Policy Simulation Database and Model. 1,21

they could potentially generate as per the Parliamentary Budget Officer's tools, including using the Social Policy Simulation Database and Model to estimate the impact of changes in different sources of public financing. ${ }^{21}$ We then conclude by proposing the use of a mix of these revenue sources.

\section{Personal income taxes}

Personal income taxes are the largest source of federal revenues and a logical option for financing some or all of the costs of national pharmacare as households will save considerable outof-pocket expenses for medicines and household-borne costs of private health insurance. ${ }^{12}$ An across-the-board 1 percentage point increase in personal income tax rates in 2020 would provide about $\$ 7.7$ billion in new federal revenues, nearly enough to implement national pharmacare. ${ }^{21}$

An increase in personal income tax will be progressive with respect to income distribution - those with higher incomes would pay more than those with lower incomes - which is widely thought to be desirable in health care financing. ${ }^{5,6}$ However, relying exclusively on personal income taxes would fail to recognize the windfall savings employers will receive with the implementation of national pharmacare. Another consideration is that existing public drug programs in Canada on average provide greater benefits to older populations and low-income households. ${ }^{22}$ As these groups tend to pay less in income taxes, it might seem unfair for them to benefit from an expansion of publicly funded drug coverage. But this concern is misplaced, as most of the increase in benefits provided by moving to a national pharmacare program would be for those not currently covered. Further, any income tax increases need not be across the board; they can be tailored not to unduly affect the poor or older people.

\section{Corporate income taxes}

Because most private sector savings come by way of reduced costs of private drug plans, corporate taxation might appear to be a progressive and symbolic source of revenue for the program. A 1 percentage point increase in the general corporate tax rate (from $15 \%$ to $16 \%$ ) would generate about $\$ 2.5$ billion in revenue. ${ }^{21}$ The federal tax rate would therefore have to increase by about 3 percentage points to raise the $\$ 8$ billion in new revenue needed to implement national pharmacare in 2020.

Although increased corporate income taxes would apply to companies both with and without private drug plans, all employers would benefit from having their employees publicly covered for prescription drugs, just as they benefit from having public insurance for medical and hospital care. ${ }^{23}$ There is no obvious and simple way to "unscramble the omelette" here, so that only those corporations benefiting from windfall cost savings on drug insurance would face an offsetting increase in their corporate income taxes, although this would occur automatically, to some extent, as they would have a smaller income tax deduction for these expenses.

A broader question, though, is what would the effects of corporate income tax increases be on the economy? The conventional wisdom is that these tax increases stifle investment and reduce employment. This concern is increased, given the recent reductions in corporate income taxes in the US. However, at the same time that corporate income taxes would increase, for a large number of firms, drug insurance costs would fall by more than the amounts of their tax increases. Therefore, corporate incomes net of taxes might increase for employers that have been providing drug insurance for their employees. It would be the opposite for firms that do not provide drug insurance. But even for these firms, an increase in their corporate income tax liabilities need not substantially reduce their investment rates.

If some of the needed federal revenue is raised by a comparatively small increase in the statutory tax rate, other factors like investment tax credits, accelerated depreciation, access to highly skilled labour and a stable political environment are likely to be far more important influences on firms' investment decisions. 


\section{Goods and Services Tax}

The GST is a substantial source of federal revenue that might be considered to fund all or part of the cost of implementing national pharmacare. An increase of 1 percentage point on the federal portion of the GST (from 5\% to 6\%) would generate $\$ 7.9$ billion in new revenues, nearly enough to fund the implementation of universal pharmacare on its own. A drawback of this approach is that GST revenues represent a larger share of disposable income for lower-income households than for higherincome households - because the GST tax base excludes savings, which tend to increase with income. The GST is also a particularly unpopular tax in the minds of Canadians, even as a source of financing for pharmacare..$^{24}$ Still, this regressivity could be substantially offset by simultaneous increases in the refundable sales tax credit in the individual income tax.

\section{Premiums or payroll taxes}

Government-levied premiums for the pharmacare program might be considered because of their transparency, and because premiums as low as $\$ 211$ per capita would fund the full $\$ 8$ billion in new revenues needed in 2020. However, as has been the experience with premiums for Quebec's drug plan, such "head taxes" are highly regressive, even if some income adjustment is built in. ${ }^{25}$ Premiums also require regular increases over time to keep up with program costs. Alternatively, pharmacare premiums could be structured as earnings-based social insurance contributions, like employment insurance. Such payroll taxes would apply to a more limited revenue base than personal income taxes and would not be as progressive as personal income taxes. Furthermore, depending on the maximum contribution under a payroll tax, this revenue source could be regressive. Payroll taxes would, however, tend to grow automatically with the economy thereby allowing the pharmacare budget to grow in step.

\section{Undertaking the detailed analysis needed}

The discussion above provides an initial sketch of the main modifiable revenue sources, and some of the major considerations involved in choosing a balanced mix among them. But many important details are still to be fleshed out, including the ways that federal income tax changes can affect provincial income taxes. Fortunately, there are capable tax simulation models, including the Social Policy Simulation Database and Model, as used by the Parliamentary Budget Officer, which can support more detailed analysis. The Advisory Council on the Implementation of National Pharmacare should avail itself of these powerful analytical tools.

\section{How should Canada proceed?}

Without national pharmacare by 2020 , Canadians could be paying $\$ 4.2$ billion more for medicines than they would need to under a universal, comprehensive public pharmacare plan. The question, therefore, isn't whether Canada can afford national pharmacare; rather, it is how government should raise the needed public revenues and, correspondingly, who should benefit from the billions of dollars in net savings as a result.
We believe there is a compelling argument for the federal government to raise the incremental revenues needed to implement this long-recommended expansion of Canadian medicare. Further, on balance we believe that it is both feasible and prudent to use a combination of federal revenue sources. These tax increases will provide the federal government with the needed incremental revenues, and they will be smaller than the substantial private sector savings that the program will generate.

Although there is no easily determined optimal mix of revenue sources, national pharmacare could be implemented, using 2020 estimates, if the federal government contributed its expected tax expenditure savings plus the revenue raised by a 0.5 percentage point increase in personal income tax rates, a 1 percentage point increase in corporate income tax rates and a 0.25 percentage point increase in the GST (see also Macdonald ${ }^{26}$ ). For the income tax increases, these could be better targeted at various kinds of tax-base broadening rather than simple statutory rate increases, which could simplify the tax system and increase its efficiency. The increases in each of these major sources of federal revenue are quite small compared with Canada's overall $\$ 2.2$ trillion economy, ${ }^{27}$ and would be offset by $\$ 13.9$ billion in reduced private spending on medicines by individuals and corporations. Thus, on balance, there will be far more winners than losers.

\section{References}

1. Budget 2018: equality and growth for a strong middle class. Ottawa: Department of Finance Canada; 2018.

2. Kesselheim AS, Huybrechts KF, Choudhry NK, et al. Prescription drug insurance coverage and patient health outcomes: a systematic review. Am J Public Health 2015;105:e17-30.

3. Morgan SG, Leopold C, Wagner AK. Drivers of expenditure on primary care prescription drugs in 10 high-income countries with universal health coverage. CMAJ 2017;189:E794-9.

4. Woolhandler S, Campbell T, Himmelstein DU. Costs of health care administration in the United States and Canada. N Engl J Med 2003;349:768-75.

5. Hurley J. An overview of the normative economics of the health sector. In: Culyer AJ, Newhouse JP, editors. Handbook of health economics. Vol 1. Amsterdam: Elesevier Science; 2000:55-118.

6. Wagstaff A, van Doorslaer E. Equity in health care finance and delivery. In: Culyer AJ, Newhouse JP, editors. Handbook of health economics. Vol 1. Amsterdam: Elsevier; 2000:1803-62.

7. Royal Commission on health services: 1964. Vol. 1. Ottawa: Queen's Printer; 1964.

8. Canada health action: building on the legacy. Ottawa: National Forum on Health; 1997.

9. Building on values: the future of health care in Canada - final report. Saskatoon: Commission on the Future of Health Care in Canada; 2002.

10. Pharmacare now: prescription medicine coverage for all Canadians: report of the Standing Committee on Health. Ottawa: House of Commons Standing Committee on Health; 2018.

11. Alignment among public formularies in Canada - Part 1: general overview. Ottawa: Patented Medicine Prices Review Board; 2017.

12. Federal cost of a national pharmacare program. Ottawa: Office of the Parliamentary Budget Officer; 2017.

13. Morgan SG, Law M, Daw JR, et al. Estimated cost of universal public coverage of prescription drugs in Canada. CMAJ 2015;187:491-7.

14. Morgan SG, Li W, Yau B, et al. Estimated effects of adding universal public coverage of an essential medicines list to existing public drug plans in Canada. CMAJ 2017; 189:E295-302. 
15. OECD Health Statistics 2018 [database]. Paris (FR): Organisation for Ecomonic Co-Operation and Development; 2018.

16. Flood CM, Thomas B, Moten AA, et al. Universal pharmacare and federalism: policy options for Canada. Montreal: Institute for Research on Public Policy; 2018.

17. Anis AH. Pharmaceutical policies in Canada: another example of federalprovincial discord. CMAJ 2000;162:523-6.

18. Towards implementation of national pharmacare discussion paper. Ottawa: Health Canada; 2018.

19. Report on federal tax expenditures: concepts, estimates and evaluations 2018. Ottawa: Department of Finance; 2018.

20. National health expenditure trends, 1975 to 2017. Ottawa: Canadian Institute for Health Information; 2017. Available: www.cihi.ca/nhex (accessed 2018 Oct. 20).

21. Research tools: Ready Reckoner. Ottawa: Office of the Parliamentary Budget Officer; 2018. Available: www.pbo-dpb.gc.ca/en/Research\%20Tools (accessed 2018 July 5).
22. Barnes S, Anderson L. Low earnings, unfilled prescriptions: employer-provided health benefit coverage in Canada. Toronto: Wellesley Institute; 2015.

23. A call for action: II. Ottawa: Canadian Automotive Partnership Council; 2013.

24. Prescription drug access and affordability an issue for nearly a quarter of all Canadian households. Vancouver: Angus Reid Institute; 2015.

25. Morgan SG, Gagnon M-A, Charbonneau M, et al. Evaluating the effects of Quebec's private-public drug insurance system. CMAJ 2017;189:E1259-63.

26. Macdonald D, Sanger T. A Prescription for Savings: Federal revenue options for pharmacare and their distributional impacts on households, businesses and governments. Ottawa: Canadian Centre for Policy Alternatives; 2018.

27. Gross domestic product, income and expenditure, second quarter 2018. The Daily [Ottawa: Statistics Canada] 2018 Aug. 30. Cat no 11-001-X.
Competing interests: Steven Morgan reports receiving personal fees for pharmaceutical policy research work for the Government of Canada, outside the submitted work. No other competing interests were declared.

This article was solicited and has been peer reviewed.
Affiliations: Faculties of Medicine and Law (Wolfson), University of Ottawa, Ottawa, Ont.; School of Population and Public Health (Morgan), University of British Columbia, Vancouver, BC

Contributors: Michael Wolfson and Steven Morgan contributed to the conception and design of the work and to the collection and interpretation of evidence. Michael Wolfson produced the first draft. Both authors revised the manuscript for important intellectual content, gave final approval of the version to be published and agreed to be accountable for all aspects of the work.

Correspondence to: Michael Wolfson, michael.wolfson@uottawa.ca 